\title{
Managing drivers of innovation in construction networks ${ }^{1}$
}

\author{
Bart A.G. Bossink \\ Faculty of Economics and Business Administration, Vrije Universiteit Amsterdam, The \\ Netherlands; E-mail: bbossink@feweb.vu.nl
}

Keywords Construction industry, Netherlands, Innovation

\begin{abstract}
Various drivers of construction innovation are distinguished and classified in four distinctive categories: environmental pressure, technological capability, knowledge exchange, and boundary spanning. Innovation drivers in these categories are active at the transfirm, intrafirm, and interfirm level in the network of organizations in the construction industry. Empirical research in the Dutch construction industry illustrates that the innovation drivers are used by managers of the authorities, clients, architects, consultants, and contractors to stimulate and facilitate innovation processes. It also exemplifies that driving innovation on the transfirm, intrafirm, and interfirm level in the network of organizations is an opportunity for managers of both public and private organizations to develop, improve, and renew: their organizations' positions in the market, the quality of their organizations' projects, and the cooperative structure of the industry as a whole.
\end{abstract}

\footnotetext{
${ }^{1}$ Paper is published as an article in the Journal of Construction Engineering and Management: Bossink, B.A.G. (2004) Managing Drivers of Innovation in Construction Networks. Journal of Construction Engineering and Management, 130(3).
} 


\section{Introduction}

Drivers of the development, design and realization of innovations in construction are explored under headings like ‘innovation leaders' and 'innovation champions' (Nam and Tatum, 1997), 'inter-firm innovation networks' (Bröchner and Grandison, 1992; Korczynski, 1996; Lampel et al., 1996; Robertson et al., 1996), and 'innovation stimulating regulations' (Bernstein, 1996; Larsson, 1996; Gann et al., 1998; Guy and Kibert, 1998; Bon and Hutchinson, 2000; Ngowi, 2001; Seaden and Manseau, 2001). There are several drivers of construction innovation and these are active at different levels in the network of cooperating organizations (Tatum, 1989; Nam and Tatum, 1992b; Winch, 1998; Gann and Salter, 2000), like for example the industry level (Pries and Janszen, 1995), the institutional and firm level (Winch, 1998), and the construction project level (Lampel et al., 1996). A related question is how the various innovation drivers can be managed at these levels (Nam and Tatum, 1989; Veshosky, 1998; Winch, 1998; Mitropoulos and Tatum, 1999; Barlow, 2000; Koskela and Vrijhoef, 2001; Miozzo and Dewick, 2002). A research project is designed and carried out to search for answers to this question. The research project is focussed on a central research question and three sub questions. The central research question is:

Which drivers of construction innovation can be distinguished and how can they be used to manage the innovation process? 
This research question is split into three sub questions:

(1) Which drivers of construction innovation can be distinguished?

(2) At which levels in construction practice do these drivers stimulate innovation?

(3) How can the innovation drivers be used to manage the innovation process?

This paper is presented in six sections. The first section contains an introduction into the central topic of the paper. The elements of the empirical research project, the data collection methods, and data analysis, are described in the second section. A literature study is carried out to provide an overview of drivers of construction innovation and to identify the levels wherein these drivers stimulate innovation. The results of the literature study are presented in the third section. Empirical research is carried out in the Dutch construction industry to describe the innovation drivers on different management levels in practice. The results of the empirical research are presented in the fourth section. An analysis is made of how managers in practice use the innovation drivers to manage the innovation process. The analysis is the subject of the fifth section. On the basis of the research findings, which are summarized in the sixth section, final conclusions are presented at the end of the paper. 


\section{Research methodology}

In this section the empirical research, data collection methods, and data analysis method are described.

\section{Empirical research}

The empirical research consisted of a literature study, an interview survey and a case study project. The literature study and the interview survey were carried out to provide an overview of innovation drivers. The purpose of the case study project was to determine the levels in construction practice at which these drivers stimulated innovation.

\section{Data collection}

In the interview survey 66 experts in construction innovation were interviewed. The experts represented various institutions and firms in the Dutch construction industry, varying from universities and scientific research institutes (three), governmental bodies (20) and non-commercial knowledge centers (one) to commercial consultants (six), architects (12), real estate agents (12) and construction companies (12). The interviews had an open structure. The innovation drivers found in the literature were the main subjects of the interviews. The interviewees were asked to reflect on the background and characteristics of the innovation drivers.

After the completion of the interview survey the case study project was carried out. In the case study project, ten construction projects were studied and documented. The 
construction projects had in common that an important project goal was to innovate in the field of sustainability. The projects that were studied are: the development of an ecological infrastructure for a residential area of 200 buildings, and nine residential building projects for 10-50 ecological buildings each.

The project for the ecological infrastructure contained a road structure, water supply facilities, hydrological arrangements, supply of electricity, parks, playing gardens, trees and greening space. In the project, various governmental institutions, designers, consultants, and contractors participated.

The nine ecological residential building projects comprised the development of houses and public utilities. In each project a troika, consisting of a real estate agent, an architect and a contractor, developed buildings and utilities with environmentally friendly materials, using energy saving approaches, and waste minimizing technology.

In each project the meetings were attended and documented. In the infrastructural construction project eight meetings and in each residential building project five meetings were attended and documented. In all ten projects the project plans, requirement schedules, rough drafts, preliminary designs, final designs, and building specifications were collected and the key informants interviewed. In the infrastructural project, the project manager representing the client, and the managers of the organizations hired by the client, were interviewed on a regular basis. In each residential construction project, representatives of the client, architectural firms, and the contractors were interviewed during the course of the project. The projects, participants and data collection methods are summarized in Table 1. 
Table 1. Projects, participants and data collection in the case study project.

\begin{tabular}{|c|c|c|}
\hline Projects & Participants & Data collection \\
\hline $\begin{array}{l}\text { A project for the ecological } \\
\text { infrastructure for a residential } \\
\text { area of } 200 \text { buildings }\end{array}$ & $\begin{array}{l}\text { - } 5 \text { municipal } \\
\text { departments } \\
\text { - } 3 \text { architectural firms } \\
\text { - } 2 \text { consultants' firms } \\
\text { - } 4 \text { contractors }\end{array}$ & $\begin{array}{l}\text { - } \text { attention and documentation of } 8 \\
\text { meetings } \\
\text { - } 28 \text { interviews with the participants } \\
\text { - } \text { gathering of project plans, requirement } \\
\text { schedules, rough drafts, preliminary } \\
\text { designs, final designs, and building } \\
\text { specifications (45 documents) }\end{array}$ \\
\hline $\begin{array}{l}\text { Nine projects for } 10-50 \\
\text { ecological buildings each }\end{array}$ & $\begin{array}{ll}\text { - } & \text { a real estate agent } \\
\text { - } & \text { a contractor } \\
\text { - } & \text { an architectural firm }\end{array}$ & $\begin{array}{ll}\text { - } & \text { attention and documentation of } 5 \\
\text { meetings (in each project) } \\
\text { - } 3 \text { interviews with the participants ( in } \\
\text { each project) } \\
\text { gathering of } 3-5 \text { project evaluation } \\
\text { reports (in each project) }\end{array}$ \\
\hline
\end{tabular}

\section{Data analysis}

An overview of innovation drivers was made on the basis of the literature study. The overview was verified in the interview survey (Emory and Cooper, 1991; Kumar et al., 1993). In the construction projects studied, it was documented at which levels in construction practice the innovation drivers stimulated innovation. The innovation drivers were traced in the meetings attended, and documented with the project plans, requirement schedules, rough drafts, preliminary designs, final designs, and building specifications that were gathered. In the interviews with the project participants it was investigated how the managers used the innovation drivers to stimulate innovation processes. These explanations were verified in the meetings attended and by analyzing the project plans, requirement schedules, rough drafts, preliminary designs, final designs and building specifications (Eisenhardt, 1989; Cunningham, 1997; Wilson and Vlosky, 1997; Yin, 1999). 


\section{Drivers of innovation in construction networks}

In this section an overview of drivers of construction innovation on different levels in the network of organizations in construction practice is presented. The overview is based on the literature study and is used as a framework to describe and analyze the results of the empirical research.

Four categories of innovation drivers can be distinguished. The first is environmental pressure. This category comprises the influences that force and stimulate organizations to innovate (Tatum, 1989; Pries and Janszen, 1995; Toole, 1998; Winch, 1998; Gann and Salter, 2000). The second category is technological capability. This category consists of technical factors enabling organizations to develop innovative products and processes (Bröchner and Grandison, 1992; Nam and Tatum, 1992a; Nam and Tatum, 1997; Gann and Salter, 2000; Mitropoulos and Tatum, 2000). The third category is knowledge exchange. This category consists of the arrangements that facilitate the sharing of knowledge and information that is needed to innovate in and between organizations (Slaughter, 1993; Kangari and Miyatake, 1997; Toole, 1998; Veshosky, 1998; Gann and Salter, 2000; Goverse et al., 2001). The fourth category is boundary spanning. This category represents the initiatives to co-innovate across the boundaries of departments, organizations and partnerships (Tatum, 1989; Arditi et al., 1997; Barlow, 2000; Gann and Salter, 2000; Slaughter and Shimizu, 2000). Three management levels can be discerned in the network of organizations that co-innovate in the construction industry. The first level is the intrafirm level. This level comprises the issues that are important for an 
individual organization in the industry, like for example a contractor, an architectural firm, or a professional client (Tatum, 1989; Slaughter, 1993; Lampel et al., 1996; Toole, 1998; Veshosky, 1998). The second level is the interfirm level. This level represents the projects in which organizations cooperatively develop and build objects (Tatum, 1989; Bröchner and Grandison, 1992; Nam and Tatum, 1992b; Winch, 1998; Bresnen and Marshall, 2000). The third level is the transfirm level. The transfirm level exceeds the intra- and interfirm level and comprises issues that are important for the industry as a whole of interrelated firms and institutions (Pries and Janszen, 1995; Winch, 1998; Goverse et al., 2001; Seaden and Manseau, 2001). In Table 2 the innovation drivers are categorized, and the management levels in the construction network at which these drivers stimulate innovation is provided. 
Table 2. Drivers of innovation in the network of organizations

\begin{tabular}{|c|c|c|c|}
\hline Innovation drivers & 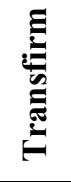 & 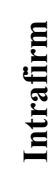 & 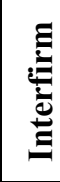 \\
\hline $\begin{array}{l}\text { Environmental pressure: } \\
\text { Market pull } \\
\text { Governmental guarantee for markets for innovative firms } \\
\text { Governmental clients with innovative demands } \\
\text { Innovation stimulating regulations } \\
\text { Subsidies for innovative applications and materials }\end{array}$ & $\begin{array}{l}X \\
X \\
\\
X \\
X\end{array}$ & $\begin{array}{l}X \\
X\end{array}$ & $\begin{array}{l}X \\
X \\
X\end{array}$ \\
\hline $\begin{array}{l}\text { Technological capability: } \\
\text { Product evaluating institutions } \\
\text { Programmes promoting access to technology } \\
\text { Finance for pilot projects } \\
\text { Technology fusion } \\
\text { Technology leadership strategy } \\
\text { Technology push }\end{array}$ & $\begin{array}{l}X \\
X \\
X\end{array}$ & $\begin{array}{l}X \\
X\end{array}$ & $\begin{array}{l}X \\
X \\
X\end{array}$ \\
\hline $\begin{array}{l}\text { Knowledge exchange: } \\
\text { Stimulation of research } \\
\text { Creation of knowledge networks } \\
\text { Programmes promoting collaboration } \\
\text { Broad view of risk } \\
\text { Integrated and informal } r \& d \text { function } \\
\text { Effective information gathering } \\
\text { Training of workers on the site } \\
\text { Lateral communication structures }\end{array}$ & $\begin{array}{l}X \\
X \\
X\end{array}$ & $\begin{array}{l}X \\
X \\
X \\
X \\
X\end{array}$ & $\begin{array}{l}X \\
X\end{array}$ \\
\hline $\begin{array}{l}\text { Boundary spanning: } \\
\text { Integration of design and build } \\
\text { Involvement of the client } \\
\text { Mechanisms for sharing financial risks and benefits } \\
\text { Coordination of participating groups } \\
\text { Empowerment of innovation leaders } \\
\text { Empowerment of innovation champions } \\
\text { Innovations from suppliers } \\
\text { Explicit coordination of the innovation process } \\
\text { Strategic alliances and long term relationships }\end{array}$ & $\mathrm{X}$ & $\begin{array}{l}X \\
X \\
X \\
X \\
X \\
X\end{array}$ & $\begin{array}{l}X \\
X \\
X \\
X \\
X \\
X \\
X \\
X \\
X\end{array}$ \\
\hline
\end{tabular}




\section{Environmental pressure}

Nam and Tatum (1992a) studied the innovations that were developed in ten construction projects in the United States and concluded that innovations were developed because of an innovation demanding market. Pries and Janszen (1995) analyzed the innovative characteristics of the Dutch construction industry from 1945 to 1995 and argued that, although some companies' strategies in the construction industry were traditionally technology oriented, these strategies changed because of the market exerting pressure to innovate. Arditi et al. (1997) investigated the innovation rate in construction equipment in the United States over a period of 30 years and found that the innovation rate increased due to market forces. Miozzo and Dewick (2002) explored the development of strategic innovations by, and the operational capabilities of, the largest contractors in Germany, Sweden, Denmark, France, and the United Kingdom. One of their conclusions was that governments were able to stimulate innovation in a construction industry by guaranteeing markets for innovative firms. Seaden and Manseau (2001) reviewed the national policies of 15 countries in Europe, North and South America, South Africa, and Japan towards innovation in construction. They presented an overview of public policy instruments that drive innovation. One of the main innovation-stimulating policy instruments were considered to be the definition of innovative wishes, demands and specifications by governmental bodies who were in the position of 'client' in construction projects. Mitropoulos and Tatum (2000) investigated the forces that drive construction firms in the United States to adopt new information technologies. One of the forces they distinguished is regulation. In addition to this, Goverse et al. (2001) studied the opportunities to increase the use of wood in the Dutch construction industry and came to 
the conclusion that to stimulate the use of wood an important focus point of policy making should be the development of regulations. Subsidies for innovative applications and materials were also mentioned by Goverse et al. (2001) as a driver of innovation, and can be part of regulatory measures. Gann et al. (1998) studied the effects of regulations on innovativeness in the construction industry in the United Kingdom. They argued that prescriptive regulations, that force organizations to innovate in conformance with detailed specifications, are traditional and stifle creativity; and that performance-based building regulations, that stimulate organizations to innovate in a certain direction, are progressive and can be an effective driver of innovation.

\section{Technological capability}

Seaden and Manseau (2001) mentioned the evaluation of new products, processes, and technologies before market launch, as an instrument to guarantee the quality of innovations. Objective institutes, responsible for the testing of the newly developed products, processes, and technologies, can assure that the industry is confronted with high quality innovations. Seaden and Manseau (2001) and Goverse et al. (2001) stressed the importance of programmes and bridging institutions facilitating access for organizations to the technology needed to innovate. In addition to this, Miozzo and Dewick (2002) stated that long-term relations between firms and external knowledge centers facilitated access to, and adoption of, new technologies in the construction industry. Miozzo and Dewick (2002) also stated that innovation could be stimulated by financial support for innovative pilot projects in which technologies are tested and evaluated before market launch. Kangari and Miyatake (1997) described factors that contributed to the 
development of innovative construction technology in Japan. One of the factors they described was construction technology fusion, which means that diverse technologies from various disciplines are integrated to develop a new construction technique, construction object or process. Nam and Tatum (1992a) stated that firms that want to be innovative should follow a technology leadership strategy. Kangari and Miyatake (1997) supported this statement and argued that a prominent reputation is built with innovation leadership. Nam and Tatum (1997) also studied the role of key individuals in ten successful innovation projects in the construction industry in the United States and concluded that technological competence is a prerequisite for effective leadership in construction and that effective leadership is essential for technological innovation in construction. Nam and Tatum (1992a), Bröchner and Grandison (1992), and Mitropoulos and Tatum (2000) concluded that solutions often precede problems and that advanced technology of designers and constructors in many cases shapes the demands of the client. Technological capabilities of organizations in the industry push the implementation of the new solutions by these organizations in their construction projects.

\section{Knowledge exchange}

Goverse et al. (2001) stressed the importance of stimulation of research in construction innovation. They also underpinned the importance of the creation, stabilization and upgrading of knowledge networks consisting of universities, research institutes, and knowledge-intensive business services. Exchange of knowledge facilitates the development of new knowledge that can be used to innovate. Seaden and Manseau (2001) mentioned programmes promoting collaborative arrangements between 
organizations as an innovation driver. One of the drivers of innovation Tatum (1989) described is a company with a broad and long-term view of risk. Nam and Tatum (1992a) stated that an integrated and informal $r \& d$ function in a firm strengthens its innovative capability. The R\&D function initiates new developments and creates attention for these developments in parts of the organization that have to work under market conditions. Kangari and Miyatake (1997), Toole (1998) and Veshosky (1998) mentioned effective information gathering as an important innovation driver. In an empirical investigation in the construction industry in the United States, Toole (1998) found that a firm's capacity to gather and process information about new technology contributed to the firm's innovativeness. Toole (1998) also concluded that building material manufacturers and retailers providing information about new products take away the designers' and contractors' uncertainty about the new possibilities and contribute to innovation in the industry. Veshosky (1998) conducted a research project in the engineering and construction industry in the United States of America and focussed on the information seeking behavior of managers. Veshosky (1998) found that firms recognizing the importance of innovation facilitated their project managers in obtaining innovation information. Slaughter (1993) conducted a study in the construction industry in the United States and reported that builders developed innovations on-site by changing application methods of components and integrating them with other elements of the construction. Innovation by workers on the site is highly stimulated when the workers are informed about new products and procedures and get the space to develop their own processing methods to work with these innovations. Barlow (2000) studied innovation in offshore construction in the United Kingdom and concluded that innovation is made 
possible by non hierarchical internal and external communication structures. In organizations and construction projects lateral communication facilitates the exchange of knowledge and stimulates innovative solutions in the process.

\section{Boundary spanning}

Tatum (1989) mentioned the integration of design and construction disciplines as an important driver of innovation. It prevents construction projects from innovative designs that cannot be constructed. Nam and Tatum (1992b) investigated several construction innovations to establish which instruments could be used to stimulate innovation in construction projects. One of the instruments they reported to be useful is the involvement of the client in the construction project. Bröchner and Grandison (1992) and Mitropoulos and Tatum (2000) also mentioned client involvement as a driver of innovation. Barlow (2000) stated that the establishment of financial mechanisms for sharing project risks and benefits is needed to ensure that innovations are defined and it is clear how costs and revenues are shared between project participants. Tatum (1989) reported that the coordination of all participating groups in the innovation process is an important innovation driver. According to Tatum (1989), Nam and Tatum (1992b) and Barlow (2000), staffing for key positions, such as innovation champions and leaders, is important in the innovation process. Innovation champions act as individual drivers of innovation in organizations and projects. Innovation leaders function as initiators and managers of the innovation processes in organizations and projects. Arditi et al. (1997) and Ben Mahmoud-Jouini (2000) illustrated that the construction industry is heavily dependent on other industries such as the construction equipment industry. Suppliers of 
innovative construction materials and construction processes contribute to the innovative capacity of organizations and their output in construction projects. Slaughter and Shimizu (2000) analyzed the nature of the innovations in the development of 11 bridges, situated in Denmark, Sweden, Japan, France, China, Canada and the United States, and concluded that to achieve multiple, inter-related innovations, the innovation processes should be explicitly coordinated. Nam and Tatum (1992b) stressed the importance of the establishment of long-term relationships between organizations in the construction industry. Kangari and Miyatake (1997) mentioned the strategic alliance as a means to leverage scientific and technical capabilities and to share the financial risks. 


\section{Drivers of innovation in sustainable construction in the Netherlands}

In this section the drivers of construction innovation in sustainability in the Netherlands are described. The description is based on the case study project. The drivers will be described under the headings of the four basic categories in the theoretical framework: environmental pressure, technological capability, knowledge exchange, and boundary spanning.

\section{Environmental pressure}

Market pull was absent as an active driver of innovation. The market did not demand sustainable areas and objects. Potential buyers were primarily interested in a high qualityprice ratio of their investment. Important quality aspects were space, location and a sunny garden. Governmental market guarantees were given to waste recycling companies. These companies were subsidized to recycle construction waste for reuse. In many construction projects the municipal authorities participated as clients and they selected real estate agents, architects and contractors who were able and willing to be innovative in sustainability. Governmental regulations stimulated the innovation processes in the projects examined. The Dutch government used the Environmental Control Act, the Building Construction Act, and the Municipality Act to oblige organizations to build according to sustainability standards. A package with sustainable demands was developed and market parties had to design and build in accordance with the demands in this package. The central provincial and municipal authorities subsidized the use of sustainable construction materials and applications, such as solar boilers, solar collectors, 
and efficient water supply systems, and these were implemented on a large scale by the organizations in the construction projects.

\section{Technological capability}

The Dutch construction industry is served by institutions that test and approve construction applications and materials. Innovative sustainable products that were evaluated and approved by these institutions, like sustainable bricks and concrete containing recycled materials, were frequently used by architects and contractors. Programmes promoting access to new technology also stimulated innovation creation. Solar boilers and solar collectors are examples of products that were promoted and made accessible for use on a large scale. The Dutch government funded pilot projects in sustainable construction all over the country to stimulate the development of sustainable innovation capabilities of commercial organizations. Almost every city in the Netherlands had a sustainable construction project that served as a benchmark for other construction projects in the municipal area. Multidisciplinary teams of town and country planners, housing architects, municipal officers, designers, and contractors joined forces to develop concepts in which their individual technological capabilities were integrated. The objects that were developed earned a high overall and nationally recognized sustainability score. Most of the professional clients' and architects' strategies focussed on being a leading organization in sustainability. Professional clients hired consultants who advised them which innovative technologies to use. The reservoir of available technology at universities and research institutes enabled clients and designers to develop highly innovative sustainable designs. 


\section{Knowledge exchange}

The government stimulated research and development in sustainability at universities and research centers. Organizations in the construction industry used sustainable material lists based on the outcomes of scientific and applied research at these institutes. The authorities also created knowledge networks for sustainable construction. Authorityfunded knowledge centers created and managed a network for the transfer of knowledge and information on sustainability and sustainable construction. The knowledge centers were well known in the country. The Dutch government promoted collaborations in sustainable construction by organizing national conferences on sustainable construction and by developing municipal information campaigns. Sustainable demonstration projects were used to inform organizations and customers about the possibilities of sustainable construction. One of the reasons for organizations to participate in sustainable construction projects was to learn and develop new capabilities and knowledge in the field of sustainability. Most of the organizations had an informal R\&D function: managers monitored new technological developments and new market demands in the environment, shared their information with colleagues, and decided if it was necessary to use new technology or to develop new markets. Organizations gathered information about design tools, checklists, and procedures that could be used to design and build sustainable objects. Access to these instruments was facilitated by the knowledge infrastructure created by the authorities. Popular design tools were checklists with sustainable materials and lists with a selection of designers and contractors who were capable of innovating in sustainability. Workers on the site were instructed how to use 
sustainable materials and how to separate waste in various fractions. Lateral communication structures were used frequently: participants in construction projects met on a regular basis to discuss the progress of the projects.

\section{Boundary spanning}

The integration of design and build activities was a common practice. Architects consulted their clients and contractors from the start of the design process to the final design stage. Some of the clients had specific wishes and demands concerning sustainability, for example, an extremely high energy efficiency ratio, and stimulated architects to come up innovative solutions and ideas. Fixed price contracts were used to share the risks and benefits of the innovation trajectories. Risk taking commercial clients invested in the projects and hired the architects and contractors for a fixed price. The clients decided to what degree it was financially wise to develop sustainable innovations and dictated the innovation ambition level in the projects. Interdisciplinary teams combined their expertise and their innovative concepts - like for example, an ecological water management system for the whole area - were implemented in the construction project. In all projects innovation leaders and champions were the driving forces behind the initiation and realization of innovative ideas. Every project had one or two managers who led the innovation process and two or three innovation champions who produced innovative ideas and developed them into useful concepts. Suppliers and consultants also introduced innovative solutions. For example, lists with sustainable materials could be obtained from consultants' firms. Although in most construction projects the innovation processes were planned and budgets were allocated, the innovation processes were not 
explicitly managed due to a lack of experience with, and knowledge about, innovation processes of the managers concerned. Most of the organizations had partners to work with. Their co-innovative capabilities were based on these partnerships that lasted for years.

\section{Managing innovation in sustainable construction in the Netherlands}

In this section we analyze how the innovation drivers were used to stimulate the innovation processes in the cases studied. For each innovation driver in the network of organizations the accompanying managerial action is identified. The analysis is summarized in Table 3. 
Table 3. Managerial actions driving innovation

\begin{tabular}{|c|c|c|c|c|}
\hline Innovation drivers & 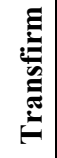 & 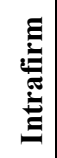 & 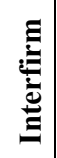 & Managerial actions \\
\hline $\begin{array}{l}\text { Environmental pressure: } \\
\text { Market pull } \\
\text { Governmental guarantee for innovative firms } \\
\text { Governmental clients with innovative demands } \\
\text { Innovation stimulating regulations } \\
\text { Subsidies for innovative applications and materials }\end{array}$ & $\begin{array}{l}X \\
X \\
X \\
X\end{array}$ & $\begin{array}{l}X \\
X\end{array}$ & $\begin{array}{l}X \\
X \\
X\end{array}$ & $\begin{array}{l}\text { Professional clients followed market demands } \\
\text { The government funded the operations of innovative firms } \\
\text { Municipal project managers stimulated innovative architects } \\
\text { Organizations followed the rules } \\
\text { Clients and architects used subsidized applications }\end{array}$ \\
\hline $\begin{array}{l}\text { Technological capability: } \\
\text { Product evaluating institutions } \\
\text { Programmes promoting access to technology } \\
\text { Finance for pilot projects } \\
\text { Technology fusion } \\
\text { Technology leadership strategy } \\
\text { Technology push }\end{array}$ & $\begin{array}{l}X \\
X \\
X\end{array}$ & $\begin{array}{l}X \\
X\end{array}$ & $\begin{array}{l}X \\
X \\
X\end{array}$ & $\begin{array}{l}\text { Architects used approved applications and materials } \\
\text { Consultants introduced innovation checklists } \\
\text { The government subsidized demonstration projects } \\
\text { Architectural firms co-created innovative design concepts } \\
\text { Organizations searched for niches in the market } \\
\text { Consultants used checklists to drive the innovation processes }\end{array}$ \\
\hline $\begin{array}{l}\text { Knowledge exchange: } \\
\text { Stimulation of research } \\
\text { Creation of knowledge networks } \\
\text { Programmes promoting collaboration } \\
\text { Broad view of risk } \\
\text { Integrated and informal r\&d function } \\
\text { Effective information gathering } \\
\text { Training of workers on the site } \\
\text { Lateral communication structures }\end{array}$ & $\begin{array}{l}X \\
X \\
X\end{array}$ & $\begin{array}{l}X \\
X \\
X \\
X \\
X\end{array}$ & $\begin{array}{l}X \\
X\end{array}$ & $\begin{array}{l}\text { Consultants developed new applications } \\
\text { Knowledge centers functioned as information brokers } \\
\text { Architects and contractors joined collaboration programmes } \\
\text { Organizations saw sustainability as an order qualifier or winner } \\
\text { R\&D-officers were coupled with the innovation projects } \\
\text { Employees obtained innovation information outside their firms } \\
\text { Contractors initiated and facilitated training } \\
\text { Employees shared information and knowledge }\end{array}$ \\
\hline $\begin{array}{l}\text { Boundary spanning: } \\
\text { Integration of design and build } \\
\text { Involvement of the client } \\
\text { Mechanisms for sharing financial risks and benefits } \\
\text { Coordination of participating groups } \\
\text { Empowerment of innovation leaders } \\
\text { Empowerment of innovation champions } \\
\text { Innovations from suppliers } \\
\text { Explicit coordination of the innovation process } \\
\text { Strategic alliances and long term relationships }\end{array}$ & $X$ & $\begin{array}{l}X \\
X \\
X \\
X \\
X \\
X\end{array}$ & $\begin{array}{l}X \\
X \\
X \\
X \\
X \\
X \\
X \\
X \\
X\end{array}$ & $\begin{array}{l}\text { Clients decided which innovative designs to build } \\
\text { Clients decided to build economically sound designs } \\
\text { Clients hired architects and contractors } \\
\text { Teams worked in conformance with the demands of the client } \\
\text { Leaders managed the innovations in the construction projects } \\
\text { Champions developed innovative ideas and stimulated others } \\
\text { Architects developed most of the innovative applications } \\
\text { Clients developed innovation ambitions and measures } \\
\text { Alliances developed and delivered sustainable innovation results }\end{array}$ \\
\hline
\end{tabular}




\section{Environmental pressure}

Market pull did not have an innovation driving effect on the innovation process. Potential buyers had traditional wishes and did not value sustainable innovations. Professional clients followed the traditional wishes of the client. The government created market space for the recycling of construction and demolition waste. Dumping costs for construction and demolition waste increased and the money was used to support the waste recycling companies. Waste recycling and recycled materials became a part of the common practices in the construction industry. In construction projects with municipal clients, the clients' demands were focussed on sustainable innovations. Municipal project managers stimulated the architects they hired to develop sustainable designs. The government developed prescriptive regulations. Organizations in the industry had to perform according to certain norms and standards. Most firms in the industry just followed the rules, or acted as if they obeyed the rules and did not develop initiatives to further improve the sustainability of their operations. The authorities had budgets to subsidize sustainable applications. They informed professional clients and architects about the subsidies, and in many projects the subsidized applications were integrated in the requirement schedules of the client and the designs of the architects.

\section{Technological capability}

Some of the new sustainable construction applications and materials were tested and evaluated. In cases where the product evaluating institutions officially approved the application or material, architects started to use them on a large scale. The authorities stimulated contact between scientific researchers. Consultants in the industry introduced 
methods to classify construction materials and design options. These methods were based on the outcomes of scientific research. The authorities funded innovative demonstration projects. In the demonstration projects, the municipal clients, architects, and contractors experimented with the newest innovations in the field of sustainable construction. The participating organizations learnt about the do's and don'ts of the innovations in practice. Fusion of sustainable construction technology was created in the construction projects by multidisciplinary teams and facilitated by municipal or professional clients. Architects, specialized in different aspects of designing and technology and working for different organizations, cooperated to create new concepts in which their insights were bundled. Some organizations decided to develop a sustainable technology leadership strategy. Clients, architects and contractors with a sustainable technology leadership strategy created their own market niche and participated in a growing number of innovative projects in the country. Dutch universities and research institutes developed sustainable technology that was used by commercial organizations in the sustainable construction projects. The increasing technological possibilities pushed the sustainable innovativeness of the projects in which these consultants participated.

\section{Knowledge exchange}

Interaction between researchers and consultants pushed the transfer of the scientific insights to the practical field. The consultants translated the scientific knowledge into practical instruments and applications. The knowledge centers facilitated and stimulated the exchange of information and knowledge about sustainability between commercial organizations in the industry. The government ran several programmes with the ambition 
of stimulating cooperation between organizations, especially small architectural firms, and contractors. With these programmes the governments enabled them to share knowledge and skills with other companies and to become an organization with sustainable competence. To become an innovative firm in the field of sustainability, organizations had, or developed, a broad view of risk. They saw sustainability as an order winner for today and an order qualifier for the future. Some of the innovative clients, architects, and contractors had an informal R\&D function and coupled this function with their projects to exchange useful information and knowledge. Innovative clients, architects and contractors depended on outside information and stimulated the information gathering activities of their employees. Trade fairs, lectures, and information meetings were attended to obtain interesting information. Contractors trained their workers on site on how to divide and collect construction waste in five fractions, and suppliers of innovative materials and equipment instructed the workers on the site how to use new products. Lateral communication structures were used by all innovating organizations in the industry on both the organizational as well as the project level. Lateral communication structures facilitated the exchange information needed to develop and implement new business processes and materials and applications in the projects.

\section{Boundary spanning}

Project partners integrated the design and build activities to facilitate the communication process between designers and builders at an early stage. Constructability assessments supported the clients in their decision which design to build. Clients managed the projects by means of budgets, planning and control activities, and this restricted the innovation 
possibilities. The clients controlled the multidisciplinary teams that developed the sustainable designs and empowered innovation leaders to initiate and manage the innovation processes in the projects. Innovation champions were empowered by the innovation leaders to develop innovative ideas, to stimulate other specialists, and to implement innovative concepts in the projects. Suppliers introduced innovative sustainable applications to architects. The clients managed the innovation development and implementation processes in the construction projects. Innovation vision and ambition was developed at the start of the project, the ambitions were exactly defined with measures, and these measures were realized in the projects with project management methods like milestones, deliverables, and project budgets. Several organizations in the industry were not capable of being innovative in the field of sustainability themselves and allied with other organizations to form an innovative combination. These alliances frequently cooperated in sustainable construction projects in the country.

\section{Summary and conclusion}

Several drivers of innovation are active at different levels in the network of cooperating organizations in the construction industry. This paper addresses the research question: 'Which drivers of construction innovation can be distinguished in this network and how can they be used to manage innovation processes?' A research project was conducted to provide answers to this question. A literature study was carried out to provide an overview of international drivers of construction innovation. The literature study was 
followed by an interview survey in which 66 Dutch experts on construction innovation were interviewed. The interviewees were asked to reflect on the background and characteristics of the innovation drivers. Then, a case study project was carried out in the Netherlands. The project consisted of ten construction projects with innovations in the field of sustainability. These projects were studied in the field and during the course of action. It was documented and analyzed at which levels in the network of cooperating organizations in practice, the innovation drivers stimulated construction innovation.

The literature study and interview survey indicated that various drivers of construction innovation can be distinguished. They were divided in four categories: environmental pressure, technological capability, knowledge exchange, and boundary spanning. Environmental pressure is the pressure that is exerted by institutions and organizations and forces and stimulates other institutions and organizations to increase their innovativeness. It consists of the elements: market pull, governmental guarantees for innovative firms, governmental clients with innovative demands, and innovation stimulating regulations and subsidies. The second category: technological capability, represents developments in the field of technology that enable institutions and organizations in the construction industry to experiment with, and actually use, innovative applications and methods in their construction projects. It consists of the elements: product evaluating institutions, programmes promoting access to technology, finance for pilot projects, technology fusion, technology leadership strategies, and technology push. The third category: knowledge exchange, represents the development and sharing of knowledge and expertise in and between organizations that is needed to innovate. It consists of the elements: stimulation of research, creation of knowledge 
networks, programmes promoting collaboration, a broad view on risk, an integrated and informal $R \& D$ function, effective information gathering, training of workers on the site, and lateral communication structures. The fourth and last category is boundary spanning, and this category represents the capability of institutions and organizations to co-innovate with other institutions and organizations. Elements that constitute this category are integration of design and build, involvement of the client, mechanisms for sharing financial risks and benefits, coordination of participating groups, empowerment of innovation leaders and innovation champions, innovations from suppliers, explicit coordination of the innovation process, and strategic alliances and long term relationships.

The literature study and the interview survey also indicated that innovation drivers are active at three levels in the network of organizations in the construction industry: the intrafirm, interfirm and transfirm level. The intrafirm level is the level of the individual organization, the interfirm level represents the projects in which the organizations cooperate, and the transfirm level stands for the industry in which the construction organizations function and in which the projects take place. In addition to this, the empirical research indicated that organizations in the Dutch construction industry innovate in the field of sustainability by using all the mentioned innovation drivers at all identified levels in the network of organizations: managerial actions of organizations were aimed at reacting to environmental pressure to innovate in the field of sustainability; organizations were developing and using technological capabilities to become innovative in sustainable construction; they invested in the sharing of knowledge about sustainability 
concepts and applications; and they integrated their competence, information and skills with others by crossing organizational boundaries.

On the intrafirm level the innovation drivers were used by the individual organizations to defend, sustain or enforce their strategic positions in the marketplace. On the interfirm level, the level of the constuction projects in which the organizations cooperated, the innovation drivers were primarily used by the organizations to improve and strengthen the cooperative ties and procedures with other participants in the project. Finally, on the transfirm level, the private organizations in the industry waited for innovation incentives and pressures to come from the authorities and then reacted. Management of innovation drivers on the intrafirm, interfirm and transfirm level in the network of organizations in construction provides both commercial and public organizations the opportunity to develop, improve, and renew their positions in the market, the quality of their projects, and the cooperative structure of the industry as a whole.

\section{References}

Arditi, D., Kale, S., Tangkar, M. (1997) Innovation in construction equipment and its flow into the construction industry. Journal of Construction Engineering and Management, 123(4), 371-378.

Barlow, J. (2000) Innovation and learning in complex offshore construction projects. Research Policy, 29(7-8), 973-989. 
Ben Mahmoud-Jouini, S. (2000) Innovative supply-based strategies in the construction industry. Construction Management and Economics, 18(6), 643-650.

Bernstein, H.M. (1996) Bridging the globe: creating an international climate of engineering and construction innovation. Industry and Environment, 19(2), 26-28.

Bon, R., Hutchinson, K. (2000) Sustainable construction: some economic challenges. Building Research and Information, 28(5-6), 310-314.

Bresnen, M., Marshall, N. (2000) Partnering in construction: a critical review of issues, problems and dilemmas. Construction Management and Economics, 18(2), 229-237.

Brewer, J., Hunter, A. (1989) Multimethod Research; A Synthesis of Styles. Sage: Newbury Park, pp. 209.

Bröchner, J., Grandison, B. (1992) R\&D cooperation by Swedish contractors. Journal of Construction Engineering and Management, 118(1), 3-16.

Cunningham, J.B. (1997) Case study principles for different types of cases. Quality \& Quantity, 31(4), 401-423. 
Eisenhardt, K.M. (1989) Building theories from case study research. Academy of Management Review, 14(4), 532-550.

Emory, C.W., Cooper, D.R. (1991) Business Research Methods. Irwin: Homewood, pp. 760.

Gann, D.M., Salter, A.J. (2000) Innovation in project-based, service-enhanced firms: the construction of complex products and systems. Research Policy, 29(7-8), 955-972.

Gann, D.M., Wang, Y., Hawkins, R. (1998) Do regulations encourage innovation? The case of energy efficiency in housing. Building Research \& Information, 26(4), 280-296.

Goverse, T., Hekkert, M.P., Groenewegen, P., Worrell, E., Smits, R.E.H.M. (2001) Wood innovation in the residential construction sector; opportunities and constraints. Resources, Conservation and Recycling, 34(1), 53-74.

Guy, G.B., Kibert, C.J. (1998) Developing indicators of sustainability: US experience. Building Research and Information, 26(1), 39-45.

Kangari, R., Miyatake, Y. (1997) Developing and managing innovative construction technologies in Japan. Journal of Construction Engineering and Management, 123(1), $72-78$. 
Korczynski, M. (1996) The low-trust route to economic development: inter-firm relations in the UK engineering construction industry in the 1980s and 1990s. Journal of Management Studies, 33(6), 787-808.

Koskela, L., Vrijhoef, R. (2001) Is the current theory of construction a hindrance to innovation? Building Research \& Information, 29(3), 197-207.

Kumar, N., Stern, L.W., Anderson, J.C. (1993) Conducting interorganizational research using key informants. Academy of Management Journal, 36(6), 1633-1651.

Lampel, J., Miller, R., Floricel, S. (1996) Information asymmetries and technological innovation in large engineering projects. $R \& D$ Management, 26(4), 357-369.

Larsson, N. (1996) Public-private strategies for moving towards green building practices. Industry and Environment, 19(2), 23-25.

Miozzo, M., Dewick, P. (2002) Building competitive advantage: innovation and corporate governance in European construction. Research Policy, 31(6), 989-1008.

Mitropoulos, P., Tatum, C.B. (1999) Technology adoption decisions in construction organizations. Journal of Construction Engineering and Management, 125(5), 330-338 
Mitropoulos, P., Tatum, C.B. (2000) Forces driving adoption of new information technologies. Journal of Construction Engineering and Management, 126(5), 340-348.

Nam, C.H., Tatum, C.B. (1989) Toward understanding of product innovation process in construction. Journal of Construction Engineering and Management, 115(4), 517-534.

Nam, C.H., Tatum, C.B. (1992a) Strategies for technology push: lessons from construction innovations. Journal of Construction Engineering and Management, 118(3), $507-524$

Nam, C.H., Tatum, C.B. (1992b) Noncontractual methods of integration on construction projects. Journal of Construction Engineering and Management, 118(2), 385-398.

Nam, C.H., Tatum, C.B. (1997) Leaders and champions for construction innovation. Construction Management and Economics, 15(4), 259-270.

Ngowi, A.B. (2001) Creating competitive advantage by using environment-friendly building processes. Building and Environment, 36(3), 291-298.

Pries, F., Janszen, F. (1995) Innovation in the construction industry: the dominant role of the environment. Construction Management and Economics, 13(1), 43-51. 
Robertson, H., Pearson, A.W., Ball, D.F. (1996) The development of networks between engineering contractors and their clients: the special case of partnering. $R \& D$ Management, 26(4), 371-379.

Seaden, G., Manseau, A. (2001) Public policy and construction innovation. Building Research \& Information, 29(3), 182-196.

Slaughter, E.S. (1993) Builders as sources of construction innovation. Journal of Construction Engineering and Management, 119(3), 532-549.

Slaughter, E.S., Shimizu, H. (2000) 'Clusters' of innovations in recent long span and multi-segmental bridges. Construction Management and Economics, 18(3), 269-280.

Tatum, C.B. (1989) Organizing to increase innovation in construction firms. Journal of Construction Engineering and Management, 115(4), 602-617.

Toole, T.M. (1998) Uncertainty and home builders' adoption of technological innovations. Journal of Construction Engineering and Management, 124(4), 323-332.

Veshosky, D. (1998) Managing innovation information in engineering and construction firms. Journal of Management in Engineering, 14(1), 58-66. 
Wilson, R.P., Vlosky, E.J. (1997) Partnering relationship activities: building theory from case study research. Journal of Business Research, 39(1), 59-70.

Winch, G.M. (1998) Zephyrs of creative destruction: understanding the management of innovation in construction. Building Research \& Information, 26(4), 268-279.

Yin, R.K. (1999) Case Study Research; Design and Methods. Sage: Thousand Oaks, pp. 171. 